\title{
Constipation associated to tension type of headache in women
}

\author{
Constipação associada à cefaleia tensional em mulheres
}

Alimohamad MADDAHIAN ${ }^{1}$, Alireza VAKILIAN²

Dear Editor, we read the article by Ozan et al. about the study of 115 women with tension type headache ${ }^{1}$, of whom 48 had constipation manifestation. We have the following comments and concerns. In our study, we reviewed the recent studies of current medicine research, such as the clinical trials and observational articles in Medline in the field of constipation and headache. Studies with non-related subjects were removed and only those with simultaneous evaluation of constipation and headache in title were selected, according to the period from 2000 to July 2017.
In our study, primary assessments showed a strong association between constipation and headache in general ${ }^{2}$ (Table 1). Although the Upper GI problem has more incidence in migraine patients ${ }^{3}$, as the result of study conducted by Ozan et al., most papers in our study have indicated a positive relation between headache (especially tension headache) and constipation, despite the study by $\mathrm{Le} \mathrm{Gal}^{4}$, in which a negative relation has been mentioned between migraine headache and constipation and we do not have explanation for this result. But the type of headache in syndrome

Table 1. Results of the studies evaluating the relation between headache and constipation.

\begin{tabular}{|c|c|c|c|c|}
\hline $\begin{array}{l}\text { Study / } \\
\text { Year }\end{array}$ & $\begin{array}{l}\text { Sample } \\
\text { size / } \\
\text { Country }\end{array}$ & $\begin{array}{l}\text { Age / Gender } \\
\text { (female) }\end{array}$ & Type of study & Results and conclusion \\
\hline $\begin{array}{l}\text { Aamodt } \\
\text { et al. } \\
(2007)\end{array}$ & $\begin{array}{l}43,7821 \\
\text { Norway }\end{array}$ & $\begin{array}{l}\text { Adult/ } \\
\text { age }>20 y / 0 \\
63.3 \%\end{array}$ & $\begin{array}{l}\text { Cross-sectional } \\
\text { study/questionnaire }\end{array}$ & $\begin{array}{c}\text { Prevalence of headache was higher in constipated patients; in } \\
\text { addition, constipation increased significantly with an increasing } \\
\text { headache frequency. There were no major differences in the relation } \\
\text { between migraine and tension headache with constipation. }\end{array}$ \\
\hline $\begin{array}{l}\text { Inaloo } \\
\text { et al. } \\
(2014)\end{array}$ & 326/Iran & $\begin{array}{l}4-12 y / 0 \\
48.2 \%\end{array}$ & $\begin{array}{c}\text { Cross-sectional study/ } \\
\text { questionnaire }\end{array}$ & $\begin{array}{l}\text { As children emotional stress can trigger both headache } \\
\text { and Gl problems, further research is needed. } \\
\text { There is a strong correlation between non-migraine } \\
\text { subtype headache and chronic functional constipation. }\end{array}$ \\
\hline $\begin{array}{l}\text { Park } \\
\text { et al. } \\
(2015)\end{array}$ & 96/Korea & $\begin{array}{l}125.9 \pm 40.2 \\
\mathrm{~m} / \mathrm{o} \\
52.1 \%\end{array}$ & $\begin{array}{l}\text { Retrospective study/ } \\
\text { questionnaire }\end{array}$ & $\begin{array}{l}\text { There may be a relation between constipation and headache. } \\
\text { Resolution of constipation improves the headache situation } \\
\text { (tension headache being most of them). }\end{array}$ \\
\hline $\begin{array}{l}\text { Rabner } \\
\text { et al. } \\
\text { (2016) }\end{array}$ & $\begin{array}{l}231 / \\
\text { Boston }\end{array}$ & $\begin{array}{l}5-18 y / 0 \\
70 \%\end{array}$ & $\begin{array}{c}\text { A retrospective study/ } \\
\text { questionnaire }\end{array}$ & $\begin{array}{c}\text { Further research on autonomic dysfunction in pediatric headache } \\
\text { is needed. There was a close correlation of constipation with } \\
\text { tension-type headaches. }\end{array}$ \\
\hline $\begin{array}{l}\text { Le Gal } \\
\text { et al. } \\
\text { (2016) }\end{array}$ & $\begin{array}{l}1072 / \\
\text { France } \\
\text { and Italy }\end{array}$ & $\begin{array}{c}6-17 y / 0 \\
49 \%\end{array}$ & $\begin{array}{c}\text { A case-control study/ } \\
\text { questionnaire }\end{array}$ & $\begin{array}{l}\text { There was a negative association between functional constipation } \\
\text { and migraine. There was no explanation for this inverse relation } \\
\text { with constipation, and future studies should explore this finding. } \\
\text { There was also no significant association between functional } \\
\text { constipation disease and tension-type headaches }\end{array}$ \\
\hline
\end{tabular}

\footnotetext{
${ }^{1}$ Ali-Ibn Abi-Talib Hospital, Clinical Research Development Unit, Rafsanjan University of Medical Sciences, Rafsanjan, Iran.

${ }^{2}$ Faculty of Medicine, Department Neurology, Non- Communicable Diseases Research Center. Rafsanjan University of Medical Sciences, Rafsanjan, Iran.

Alimohamad MADDAHIAN (iD https://orcid.org/0000-0002-3460-8722; Alireza VAKILIAN (iD) https://orcid.org/0000-0001-5413-5400

Correspondence: Alimohamad Maddahian; E-mail: baniadam000@gmail.com

Conflict of interest: There is no conflict of interest to declare.
}

Received on December 25, 2019; Accepted on January 16, 2020. 
differentiation model was not applied to our study. Maybe, if it was used, the result of our study could be different.

These results may raise the idea of the existence of a possibly unique diagnostic entity in the second classification of headache disorders, the "Headache of GI Origin".

It seems that insufficient attention is given to constipation treatment in the process of headache management in modern medical texts. On the other hand, considering constipation is the side effect of some of the medicines used for treating headaches, such as calcium channel blockers and tricyclic antidepressants ${ }^{5,6}$, paying enough attention to choose appropriate medications with no constipation as a side effect might help in a more efficient treatment of headache. Possibly, the implementation of complementary and alternative medicine (CAM) should be considered.

However, more studies are needed to clarify the relation between headache (tension headache especially) and constipation.

\section{References}

1. Ozan ZT, Tanik N, Inan LE. Constipation is associated with tension type headache in women. Arq Neuropsiquiatr. 2019 Mar;77(3):161-5. https://doi.org/10.1590/0004-282×20190015

2. Madahian A, Togha M, Movahhed M, Ghorbani Z, Dehghan S, Riahi SM, et al. Constipation and headache relationship: a narrative review on Persian medicine texts and modern literature. Indo Am J Pharm. 2017 Nov;4(11):4539-46. https://doi.org/10.5281/zenodo.1068287

3. Fazljou SMB, Togha M, Ghabili K, Alizadeh M, Keshavarz M. In commemorating one thousandth anniversary of the Avicenna's Canon of Medicine: gastric headache, a forgotten clinical entity from the medieval Persia. Acta Med Iran. 2013 May;51 (5):279-83.
4. Le Gal J, Michel JF, Rinaldi VE, Spiri D, Moretti R, Bettati D, et al. Association between functional gastrointestinal disorders and migraine in children and adolescents: a case-control study. Lancet Gastroenterol Hepatol. 2016 Oct;1(2):114-21. https://doi.org/10.1016/ S2468-1253(16)30038-3

5. Uher R, Farmer A, Henigsberg N, Rietschel M, Mors O, Maier W, et al. Adverse reactions to antidepressants. Br J Psychiatry. 2009 Sep;195(3):202-10. https://doi.org/10.1192/bjp.bp.108.061960

6. Russell RP. Side effects of calcium channel blockers. Hypertension. 1988 Mar;11(3 Pt 2):I/42. https://doi. org/10.1161/01.HYP.11.3_Pt_2.II42 